\title{
Eagles and Sheep: A Viewpoint
}

\section{ERIC G. BOLEN}

Highlight: The controversy regarding golden eagle predation on lambs in the Southwest was addressed using winter eagle population data from Texas and eastern New Mexico, cagle food habits information, and lamb mortality data. The sum of this review indicates that too few lambs are eaten as prey to justify persecution of golden eagles for the presumptive enhancement of livestock production. An inquiry concerning brush cover and carnivore food habits suggests that lagomorphs, a staple in golden eagle diets, decline as usable food for carnivores where brush prevails on lambing ranges.

Above the plains and remote mountains throughout much of the Northern Hemisphere the skies are ruled by one of the world's larger avian predators, the golden eagle (Aquilia chrysaetos). Indeed, this awesome raptor caps the ecological pyramid in grassland systems and other grazing communities where stockmen, like eagles, live from the land and its richness.

The extent and nature of livestock losses to golden eagles, then, fosters controversy wherever sheep are pastured and eagles soar. Predation, perhaps like no other ecological subject, perennially generates more heat than light among and within scientific and lay communities. I nonetheless want to present my point of view regarding eagle-livestock relationships, using a synthesis of data from various sources as applied to golden eagle and sheep populations in portions of Texas and New Mexico.

Topics discussed include (1) golden eagle populations, (2) eagle foods, (3) lamb losses in the field, and (4) some speculation concerning the influence habitat conditions may exert on predation.

\section{Aerial Census of Wintering Eagle Populations}

Aerial censuses of eagles were made in 1963-1968 using light aircraft manned with a pilot and one observer flying at altitudes ranging from 100-300 feet. Each study area was covered by a randomly located transect divided into 50-mile segments. All eagles within 0.25 mile on either side of the aircraft were included in the census; $5 \%$ of the study area was sampled in Texas and $7 \%$ in New Mexico. The study areas in each state were located in major livestock-producing regions.

Originally, a 14,500 square mile study area was flown in Texas; the area spanned portions of the Edwards Plateau and Trans-Pecos regions. However, census flights over this area in the winters of 1963-64 and 1964-65 detected so few eagles that further efforts were abandoned and, subsequently, three new areas were selected based on the persistent complaints of

\footnotetext{
The author is assistant director, Rob and Bessie Welder Wildlife Foundation, Sinton, Texas.

The report is Rob and Bessie Welder Wildlife Foundation Contribution No. 163 .
}

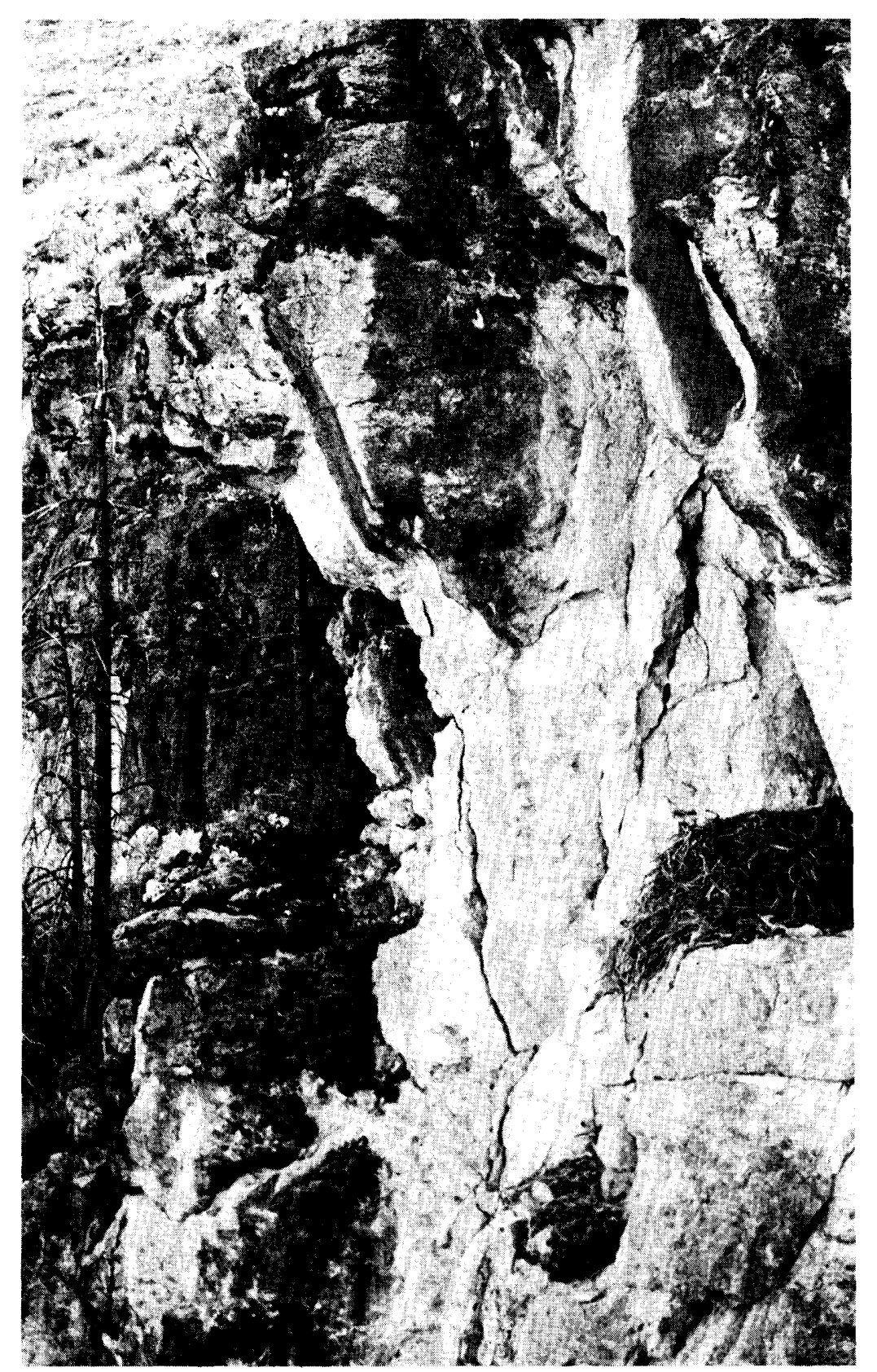

Golden eagle nest in the Southwest. Bones and other debris in nests provide a useful measure of eagle food habits, but not prey from carrion. Adult and young birds alike are sometimes killed at nest sites by persons concerned with livestock losses. Regrettably, few golden eagles still nest in Texas and New Mexico. 
Table 1. Golden eagle transect census, estimated total population, and density as determined from a $5 \%$ aerial sample of the 4,500 -square mile Trans-Pecos study area, Texas, 1966-68. (After Boeker and Bolen, 1972.)

\begin{tabular}{|c|c|c|c|c|c|c|c|c|c|}
\hline \multirow[b]{3}{*}{ Month } & \multicolumn{9}{|c|}{ Number of golden eagles } \\
\hline & \multicolumn{3}{|c|}{1966} & \multicolumn{3}{|c|}{1967} & \multicolumn{3}{|c|}{1968} \\
\hline & $\overline{\text { Counted }}$ & Population & Density $^{\mathbf{a}}$ & Counted & Population & Density & Counted & Population & Density \\
\hline January & 3 & 60 & 1.3 & 8 & 160 & 3.5 & Not flown & - & - \\
\hline February & 3 & 60 & 1.3 & 5 & 100 & 2.2 & 7 & 140 & 3.1 \\
\hline March & 5 & 100 & 2.2 & 1 & 20 & 0.4 & 5 & 100 & 2.2 \\
\hline April & 4 & 80 & 1.7 & 2 & 40 & 0.9 & 3 & 60 & 1.3 \\
\hline
\end{tabular}

${ }^{\mathrm{a}}$ Eagles per 100 square miles.

stockmen about eagle depredations. These were (Unit 1): 4,500 square miles in the Trans-Pecos counties of Presidio, Jeff Davis, Culberson, and Hudspeth; (Unit 2): 5,000 square miles in the lower Edwards Plateau including Kerr, Edwards, Bandera, Real, Kenney, Uvalde, and Medina counties; and (Unit 3): 2,400 square miles in the central Edwards Plateau counties of McCullogh, San Saba, Llano, Lampasas, and Mason.

Nonetheless, even this refinement of the census effort showed that the golden eagle population in Texas was largely confined to the Trans-Pecos region (Table 1). Few, if any, birds were counted in either of the two Edwards Plateau census units: in Unit 2, no eagles were counted in 1966, 1967, or 1968; in Unit 3, three eagles were counted in 1966, none in

Table 2. Golden eagle transect census, estimated total population, and density as determined from a $7 \%$ aerial sample of a 10,000 -square mile study area, New Mexico, 1963-68. (After Boeker and Bolen, 1972.)

\begin{tabular}{|c|c|c|c|}
\hline \multirow{2}{*}{$\begin{array}{c}\text { Year and } \\
\text { month }\end{array}$} & \multicolumn{3}{|c|}{ Number of grolden eagles } \\
\hline & Counted & Population & Density ${ }^{a}$ \\
\hline \multicolumn{4}{|l|}{$1963-64$} \\
\hline November & Not flown & - & - \\
\hline December & Not flown & - & - \\
\hline January & Not flown & - & - \\
\hline February & 27 & 386 & 4 \\
\hline March & 25 & 357 & 4 \\
\hline April & 7 & 100 & 1 \\
\hline \multicolumn{4}{|l|}{$1964-65$} \\
\hline November & Not flown & - & - \\
\hline December & 49 & 700 & 7 \\
\hline January & 40 & 572 & 6 \\
\hline February & 45 & 643 & 6 \\
\hline March & 52 & 744 & 7 \\
\hline April & 3 & 43 & 0.5 \\
\hline \multicolumn{4}{|l|}{$1965-66$} \\
\hline November & Not flown & - & - \\
\hline December & Not flown & - & - \\
\hline January & 48 & 686 & 7 \\
\hline February & 60 & 858 & 9 \\
\hline March & 18 & 257 & 3 \\
\hline April & Not flown & $\therefore$ & - \\
\hline \multicolumn{4}{|l|}{$1966-67$} \\
\hline November & Not flown & - & - \\
\hline December & Not flown & - & - \\
\hline January & 63 & 901 & 9 \\
\hline February & 55 & 786 & 8 \\
\hline March & 21 & 300 & 3 \\
\hline April & Not flown & - & - \\
\hline \multicolumn{4}{|l|}{$1967-68$} \\
\hline November & 64 & 915 & 9 \\
\hline December & 58 & 829 & 8 \\
\hline January & 62 & 887 & 9 \\
\hline February & Not flown & - & - \\
\hline March & Not flown & - & - \\
\hline April & Not flown & - & - \\
\hline
\end{tabular}

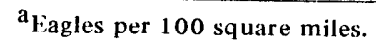

1967, and two in February of 1968.

In summary, the census indicated - year after year -that too few eagles are present in either of the Edwards Plateau regions (Units 2 and 3 ) to substantiate claims of excessive eagle predation on lambs. Conversely, the number of birds in the Trans-Pecos (Unit 1) reached levels where damage to livestock might conceivably become an economic problem (i.e., 3.5 eagles per 100 square miles).

In southeastern New Mexico, an aerial census of a 10,000 square mile study area including portions of Lincoln, Chaves, Lea, Roosevelt, Curry, DeBaca, Guadalupe, and Torrance counties revealed eagle populations significantly larger than those present in Texas (Table 2). The population on the New Mexico study area reached an estimated peak of 915 eagles, or 9 birds per 100 square miles during the 5 years of study.

In both Texas and New Mexico, much of the eagle population wintering in these states begin their spring departure in March. Accordingly, when the migration schedule dates are compared with the lamb docking data for the Trans-Pecos region of Texas (Table 3), it seems clear that a large proportion of lambs are born after the eagle population has departed. Docking dates for New Mexico are not available, yet it is well known that lambing takes place even later in New Mexico than in Texas, so that there is even less likelihood of large numbers of winter eagles being present at the time lambing takes place.

Bent (1937:315) gives the egg dates for golden eagles in the western United States as February 9 to May 18 (272 nests) and February 26 to March 24 (136 nests); for birds nesting in the arctic, the dates were May 27 to June 29 (5 nests). Arrival dates for golden eagles migrating to Alaska were listed as April 5, March 10, March 27, April 3, and April 8.

Table 3. Regional lamb docking percentages for two livestock areas, Texas, 1966-67. (After U.S. Department of Agriculture, Livestock and Crop Reporting Service statistics.)

\begin{tabular}{lcc}
\hline \hline Month & Trans-Pecos & Edwards Plateau $^{\mathrm{a}}$ \\
\hline October & - & 2 \\
November & - & 6 \\
December & 1 & 6 \\
January & 3 & 10 \\
February & 8 & 21 \\
March & 23 & 34 \\
April & 39 & 17 \\
May & 23 & 3 \\
June & 3 & trace \\
July & trace & trace \\
Total & 100 & 100
\end{tabular}

${ }^{a}$ This region contained so few wintering eagles that censuses were discontinued (see Boeker and Bolen, 1972); the docking data for the Edwards Plateau are shown here to illustrate that lambing occurs progressively later in the year as one moves westward into the TransPecos region.

$\mathrm{b}_{\text {Month }}$ eagle migration begins. 
Table 4. Frequency of occurrence for transect segments with varying densities of golden eagles, New Mexico, 1966. (After Boeker and Bolen, 1972.)

\begin{tabular}{|c|c|c|c|c|c|c|c|c|}
\hline \multirow[b]{2}{*}{$\begin{array}{c}\text { Density } \\
\text { class }\end{array}$} & \multicolumn{2}{|c|}{ January } & \multicolumn{2}{|c|}{ February } & \multicolumn{2}{|c|}{ March } & \multicolumn{2}{|c|}{ Total } \\
\hline & $\begin{array}{c}\text { Number of } \\
\text { segments }\end{array}$ & Percent & $\begin{array}{c}\text { Number of } \\
\text { segments }\end{array}$ & Percent & $\begin{array}{c}\text { Number of } \\
\text { segments }\end{array}$ & Percent & $\begin{array}{c}\begin{array}{c}\text { Number of } \\
\text { segments }\end{array} \\
\end{array}$ & Percent \\
\hline 0 & 7 & 25 & 6 & 21 & 19 & 68 & 32 & 38 \\
\hline 4 & 7 & 25 & 5 & 18 & 4 & 14 & 16 & 19 \\
\hline 8 & 8 & 29 & 3 & 10 & 3 & 10 & 14 & 17 \\
\hline 12 & 3 & 10 & 9 & 32 & 1 & 4 & 13 & 15 \\
\hline 16 & 0 & - & 4 & 14 & 0 & - & 4 & 5 \\
\hline 20 & 2 & 7 & 0 & - & 1 & 4 & 3 & 4 \\
\hline 24 & 1 & 4 & 1 & 4 & 0 & - & 2 & 2 \\
\hline Total & 28 & 100 & 28 & 100 & 28 & 100 & 84 & 100 \\
\hline
\end{tabular}

${ }^{a}$ Fagles per 100 square miles $(0-8=$ low density; $12=$ moderate; $16-24=$ high $)$.

The relatively large numbers of eagles wintering in New Mexico enable some estimates to be developed for the density that eaglcs might reach locally (as if attracted by a ready food supply, for example). This was done by converting the linear transect data into area units in the following way:

10,000 miles $^{2}$ in study area $=357$ miles $^{2}$ per linear segment Sampled by transects of 28

segments each 50 miles long

If, for example, one cagle was seen in one of the segments, this represented an overall population estimate of 14 eagles for that linear segment (the transects sampled $7 \%$ of the area); hence, the density is:

$$
\frac{357 \text { miles }^{2}}{14 \text { eagles }}=25 \text { miles }^{2} \text { per eagle or, } 4 \text { eagles per } 100 \text { miles }^{2}
$$

When the population data are converted in this way, a frequency distribution can be presented to show the percentage of the transect segments with various eagle densities (Table 4). As shown, the bulk of the transects lacked significant concentrations of eagles.

In January, 1966, when the total estimated eagle population consisted of 686 birds, $50 \%$ of the entire New Mexico study area fell into density classes of four eagles or fewer per 100 square miles, and high densities occurred only on $11 \%$ of the segments. The estimated eagle population in February, 1966, was even larger (858 birds, Table 2). This increase in total numbers, however, raised the high-density classes to $18 \%$ of the total, an increase of only $7 \%$. Slightly less than one-third $(32 \%)$ of the segments contained a moderate population density. By March, 1966, the wintering population was markedly less (257 eagles), and there were no sightings of eagles on nearly $70 \%$ of the segments. It seemed that after the population peaked in February, the eagles still in New Mexico did not often remain in dense pockets. At no time in $1966 \mathrm{did}$ more than $18 \%$ of the segments show high eagle concentrations. Such information suggests that significant eagle depredations, if occurring at all, arc local phenomena.

The census data thus bear three points. First, that wintering golden eagles in Texas are essentially absent from the major lamb producing area encompassed by the Edwards Plateau. Secondly, that where sizable eagle populations do exist in Texas and New Mexico, they have often departed before or at the time many lambs are born. Finally, even at maximum population levels, irrespective of season, eagles are seldom bunched in concentrations wherein predation leading to significant economic losses might occur.

\section{Eagle Foods}

Examination of eagle nests for the skeletal remains of their foodstuffs (prey as well as carrion) has been a traditional method of determining eagle food habits (cf. McGahan, 1967, 1968; Mollhagen et al., 1972). These and other studies have repeatedly determined that the mainstays of the golden eagle diet were lagomorphs and rodents. The results of one study, made from 41 nests in Texas and New Mexico, are shown in Table 5. Here it is shown that livestock remains were present in $70 \%$ of the nests, but only in minimal amounts (i.e., less than 2 lambs or kids per nest on the average).

It is important to emphasize that the nest collections undoubtedly represent the accumulation of several years' materials, so that the number of items taken per year per nest were even less than shown. However, there is no way to differentiate the data further so that an annual estimate of the numbers of individuals in the diet can be determined.

Moreover, as golden eagles feed in part on carrion, the materials found in the nests may or may not represent outright destruction of otherwise healthy prey. The regrettable and illegal poisoning of eagles in Wyoming, discovered in 1971, necessarily relied on the birds eating carrion baits.

As suggested earlier by the population analysis, the food habits data again indicate that the matter of lamb predation is quite local in nature; 14 of the 66 sheep represented in the sample came from a single nest.

Finally, note that of the 41 nests examined by Mollhagen et al. (1972), only one was currently active when the food materials were collected. Hence, with so few nesting eagles remaining in the Southwest, it seems rather unlikely that the nesting population renders meaningful damage to the livestock industry.

Table 5. Golden eagle food habits based on 6,981 items collected from 41 nests, Texas and New Mexico. (After Mollhagen et al., 1972.)

\begin{tabular}{lcc}
\hline \hline Food & $\begin{array}{c}\text { Nests with } \\
\text { food (\%) }\end{array}$ & $\begin{array}{c}\text { Animals in } \\
\text { diet (No.) }\end{array}$ \\
\hline Jackrabbit & 93 & 487 \\
Cottontail & 80 & 166 \\
Rock squirrel & 59 & 101 \\
Sheep and goat & 70 & $66^{\mathrm{a}}$ \\
Others (17 species) & - & 126 \\
\hline
\end{tabular}

$a_{1.6}$ individuals per nest average. although this undoubtedly represents many more than one year's accumulation of food so that the number of lambs per nest per year is far less than this figure indicates. One nest contained 14 individuals, which indicates again the local nature of lambs in the eagle diet whether as carrion or prey. 


\section{Lamb Mortality}

Lamb mortality rates have been studies under controlled conditions in a few instances. Even with supervised lambing, mortality may vary from $7-24 \%$, with most losses encountered within 2 weeks following birth. The best supervision at birth will probably not reduce losses much below $7-10 \%$ because of stillbirths and difficult lambings. This is magnified where natural lambing abilities may have been altered by artificial sclection for other traits, thus saving lambs from strains that might otherwise be unable to perpetuate themselves under field conditions. Another factor involved is the trend toward a small, compact type of sheep with a high rate of multiple births.

Unassisted lambing on the open range, as practiced in Texas and New Mexico, might conceivably produce a somewhat higher rate of survival as the "unfit" strains are presumably culled year after year by the rigors of field conditions, but the point remains speculative. Nor are data available comparing supervised with unsupervised lambing in the Southwest. However, reports concerning range sheep of similar breeding in Montana do show that high mortality rates are experienced under systems of management, including lambing in sheds. Safford and Hoversland (1960) report that 23.5\% of 7,191 range lambs died between birth and weaning, with $73 \%$ of the deaths occurring within the first 6 days following birth. Although shed-lambed, these lambs were still subject to colder climatic conditions than lambs produced in the Southwest. Vetter et al. (1960) cite 15\% mortality rates for single lambs as compared to $23 \%$ for twins. Rambouillet sheep had a $15 \%$ mortality rate as compared to $23 \%$ for Hampshire and $21 \%$ for Southdown sheep.

Exposure is undoubtedly a major influence on the success of lambing operations. The results of threc tests dividing experimental flocks into equal groups revealed that exposure to weather alone -no predation was involved-rendered severe losses to lamb crops (Table 6). Using U.S. Department of Agriculture statistics, Wagner (1972) established that, overall, about $10-11 \%$ of the sheep produced in Texas and New Mexico are lost each year to a variety of decimating agents (Table 7). Moreover, the latter data suggest that there has been little change in these losses in the 48-year period with or without poisoning control of predators such as coyotes. Hence, it seems reasonable that either (a) predators take such small numbers of lambs each year that these losses do not influence the overall loss of lambs or, (b) that the predators are taking many lambs already weakened and dying from other causes. In the latter instance, the predatory and nonpredatory losses are acting in a compensatory manner so that the predators are actually taking many lambs that would not survive anyway. The result is that the losses would be much

Table 6. Effect of shelter during lambing on lamb mortality. ${ }^{a}$ (After Rowley, 1970.)

\begin{tabular}{lrrr}
\hline & \multicolumn{3}{c}{ Test group } \\
\cline { 2 - 4 } Treatment & 1 & 2 & 3 \\
\hline Exposed & 62 & 52 & 173 \\
No. lambs born & 25 & 21 & 54 \\
No. lambs dying & & & \\
Sheltered & 62 & 53 & 163 \\
No. lambs born & 1 & 1 & 9 \\
No. lambs dying & & \\
\hline
\end{tabular}

all mortality associated with weather and failure to establish ewelamb bond. No predation.

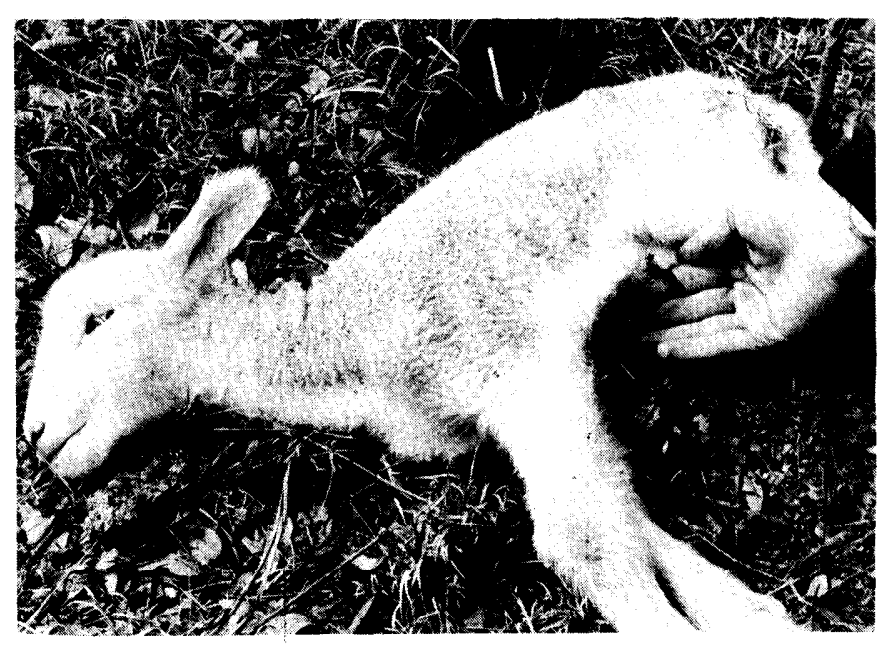

Carcass in a lambing pasture showing no external evidence of predation or scavenging. Note umbilical cord. When, at a later date, decay and/or scavenging have obliterated much of the carcass, deaths like this may be mistakenly blamed on predators.

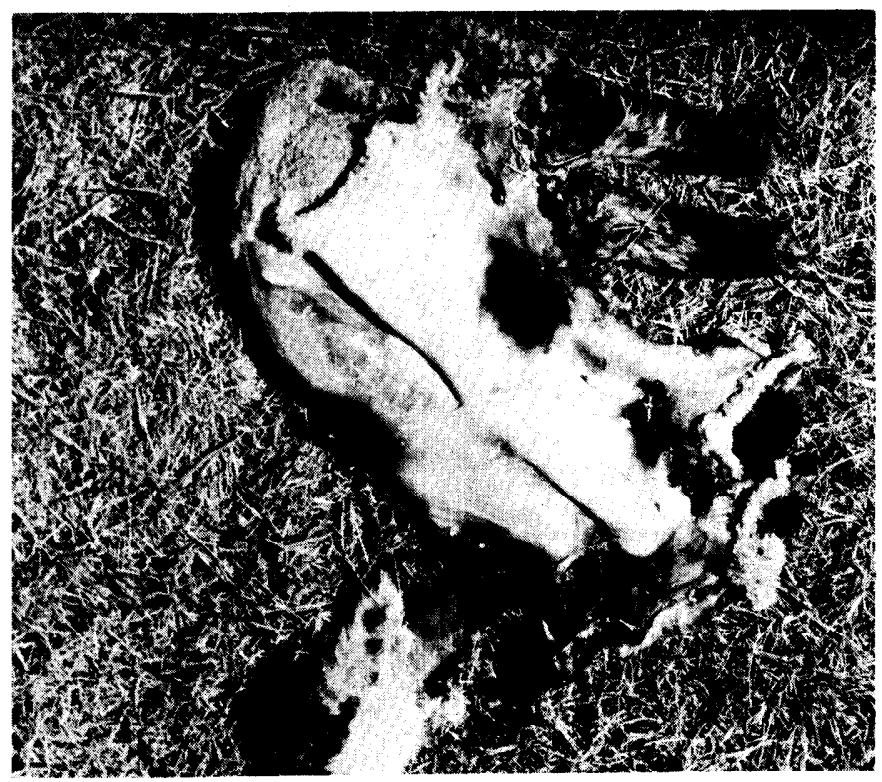

Subcutaneous hemorrhages, exposed here on a partially skinned lamb carcass, indicated that the wounds were inflicted while the lamb was alive; absence of such hemorrhages suggests the animal was already dead when the wound occurred. Internal examinations of fresh carcasses help identify the state of the lamb's health at the time of death (see text).

Table 7. Mean annual loss of sheep from all causes for Western states. (After Wagner, 1972.)

\begin{tabular}{|c|c|c|c|}
\hline \multirow[b]{2}{*}{ Locale } & \multicolumn{3}{|c|}{ Percent ${ }^{\mathrm{a}}$} \\
\hline & 1924-39 & $1940-49$ & $1950-70$ \\
\hline Texas & 9.4 & 10.3 & 11.3 \\
\hline New Mexico & 10.9 & 10.5 & 10.8 \\
\hline Others ${ }^{b}$ & $8.5-12.2$ & $7.9-11.7$ & $7.0-10.3$ \\
\hline Mean & 10.0 & 9.6 & 9.4 \\
\hline
\end{tabular}

a Data separated by time to indicate an early period when records are perhaps less accurate (1924-39), a period immediately prior to the use of 1080 poison (1940-49), and a period when 1080 has been in continuous use (1950-70).

${ }^{b}$ Montana, Wyoming, Idaho, Utah, Nevada, Colorado, and Arizona. 
the same with or without predation (Wagner, 1972). These ideas are rather similar to the concepts so lucidly developed by Errington (1967 and earlier).

The large numbers of lambs starving on Australian ranges at the time of their death certainly suggests that starvation is prevalent in many lambing situation; in seven studies summarized by Rowley (1970), 30-60\% of the dead lambs, although born alive, were starving at death. These studies included examinations of 157 to 4,417 carcasses. Such lambs become increasingly easy victims for predators, and since lamb starvation is usually irreversible, it is financially insignificant whether or not predation hastens the inevitable loss of these lambs (Rowley, 1970).

Criteria for determining the state of a lamb's condition at the timc of death include (a) lung aeration, (b) pericardial fat deposition, (c) presence of hoof membranes, (d) presence of milk and its rate of absorption in the lacteals of the small intestines, and (e) the presence of distinct thrombi at the ends of the umbilical arteries. Such criteria, as well as the physical nature of talon and other wounds present on a carcass (see Wiley and Bolen, 1971; Alford and Bolen, 1972; White, 1973; and others), enable appraisals of the ecological situation at the time prey species succumb. Rowley (1970) thus determined that over $50 \%$ of the lambs actually killed by predators were in fact already weakened and dying when they were attacked.

Wiley and Bolen (1971) made extensive searches of lambing pastures in Texas and $\mathrm{New}$ Mexico and concluded that $25 \%$ of the carcasses they found were killed by predators; the balance were stillbirths or other forms of mortality not associated with predation.

Armed with the foregoing, one can now make some approximations regarding the role of eagles in the Trans-Pecos area (the only livestock region of Texas where eagles were consistently seen in significant numbers). According to the Livestock and Crop Reporting Service (1968), the Trans-Pecos area produced some 250,000 lambs in 1966-67. Of these, we can expect that overall loss of about $10 \%$, or 25,000 dead lambs. About $25 \%$ of these deaths (i.e., 6,500 lambs) are caused by predators, but allowing that the majority of these were no doubt already in declining health when falling victim to a predator, the actual loss of otherwise healthy lambs is more nearly estimated as only 3,125 (i.e., $50 \%$ of 6,500 ). And of these, only a part-and I think the data will indicate that it is a small part indeed-can be assigned as the prey of golden eagles.

\section{Habitat Conditions}

Not withstanding our special interest in domestic animal populations as potential prey, it must be emphasized that there are probably few reliable criteria as to what constitutes optimal habitat (here meaning shelter, and not food, water, and similar factors) for lambs and kids. Moreover, the adaptations of domestic animals to select habitats are often less than clear, especially when the vicissitudes of predation are considered. Contrariwise, the adaptations and ecological requirements of native wildlife are better understood in many instances. It is difficult to describe similar circumstances for animals whose hereditary structure has been altered through countless generations of domestic manipulation rather than by rigorous natural selection.

Certainly some of the behavioral mechanisms leading to survival have been effectively reduced by domestication. Many ranchers, nonetheless, hope to induce a high degree of "wildness" in their herds as protection against environmental stresses, presumably including predation. At the same time, most ranchers remain cautious when approaching a ewe and her lamb, because of the uncertain integrity of the ewe:lamb family bond. Ranchers suggest that such disturbances might indeed separate the lamb from its mother.

Hence, it seems likely that many of the behavioral mechanisms-in addition to any physical adaptations-of apparent survival value to native wildlife are presumably much less effective or even absent in domestic sheep and goat herds. Furthermore, even if domestic animals have maintained the protective behavioral mechanisms of their wild forebears, the probability remains that the modified habitat in which they live perhaps negates the effectiveness of these traits.

Habitat situations where the separation of a ewe from her lamb might be enhanced, where there is lack of adequate cover for native prey species, or those where cover may give undue advantage to a predator represent ecological compromises regarding the impact of predation on livestock. In other words, certain habitat conditions quite likely jeopardize an otherwise relatively secure prey population.

My colleague, Robert W. Wiley, and I attempted to examine these relationships as they might apply to eagle-livestock problems in the Southwest. We did so by sampling brush cover in livestock pastures using $1,000-\mathrm{ft}$ line transects run at random in major vegetation types in two areas of the Edwards Plateau (Schleicher and Menard counties; and farther southwest in Val Verde and Terrell counties) and in the Trans-Pecos region including Texas (Culberson County) and New Mexico (Eddy and Otero counties). The transect data, converted to percentage cover, presumably reflect the amount of cover that a predator or prey (either domestic of wild) might utilize in these ranching areas. Additional data concerning eagle food habits and livestock losses were also available for our concurrent use (Mollhagen et al., 1972; Wiley and Bolen, 1971). We also conducted extensive roadside surveys for estimates of regional lagomorph populations; these were run at night beginning at $10 \mathrm{pm}$ along ranch roads that traversed lambing areas.

Results from the brush surveys showed that total cover in the Schleicher-Menard area was slightly in excess of $15 \%$; whereas in the Val Verde-Terrell area, brush covered about $22 \%$ of the ground area (Table 8 ). In the Trans-Pecos region, the transect data confirmed the rather barren terrain so striking to the eye; we found a remarkably thin amount of cover $(6.2 \%)$ in this area.

Whereas a multitude of complex relationships certainly exist between an animal and its habitat requirements, especially regarding cover, four situations seem of immediate concern: (1) that brush cover protects lambs from eagles, presumably because of the birds' reduced maneuverability; Ford and Alcorn (1964) thought that high brush kept an caglc from making full contact with a coyote the bird was attacking as the two predators fought over the carcass of a jackrabbit; (2) that brush cover enhances the separation of lambs from ewes, with the result that all types of mortality among lambs is increased, or that the brush better serves as cover for predators (especially terrestrial predators) thia it does for prey; (3) that open habitats, free of dense cover, provide favorable environments for natural prey (wildlife, especially lagomorplis) of higher availability or food preference to eagles than livestock; or (4) that open habitats favor the vulnerability of lambs to eagle predation, perhaps independently of 
Table 8. Canopy cover as measured by linear feet of shrub cover on lambing ranges, Texas and New Mexico. (Data jointly compiled by Robert W. Wiley and Eric G. Bolen.)

\begin{tabular}{|c|c|c|c|c|}
\hline \multirow[b]{2}{*}{ Region } & \multirow{2}{*}{$\begin{array}{c}\text { Physiographic } \\
\text { sites } \\
\end{array}$} & \multirow{2}{*}{$\begin{array}{l}\text { Sample } \\
\text { size (ft) }\end{array}$} & \multicolumn{2}{|c|}{ Total canopy cove } \\
\hline & & & Feet & Percent \\
\hline $\begin{array}{l}\text { Central } \\
\text { Edwards } \\
\text { Plateau }^{\mathrm{a}}\end{array}$ & $\begin{array}{l}\text { Upland oak; scrub } \\
\text { slope; mesquite } \\
\text { flat }\end{array}$ & 6,000 & 922.5 & 15.3 \\
\hline $\begin{array}{l}\text { Southwest } \\
\text { Edwards } \\
\text { Plateau }\end{array}$ & $\begin{array}{l}\text { Mesquite flat; rocky } \\
\text { hillside; upland slope; } \\
\text { lowland flat }\end{array}$ & 8,000 & 1796.0 & 22.4 \\
\hline $\begin{array}{l}\text { Trans- } \\
\text { Pecos }\end{array}$ & $\begin{array}{l}\text { Cholla flat; creosote } \\
\text { flat; western slopes; } \\
\text { northwestern slopes; } \\
\text { canyon bottom }\end{array}$ & 13,000 & 801.5 & 6.2 \\
\hline
\end{tabular}

${ }^{a_{S}}$ chleicher and Menard counties, Texas. Principal species include Shumard red oak (Quercus shumardit) $(8.3 \%)$, honey mesquite (Prosopis glandulosa) (5.7\%), Lindheimer pricklypear (Opuntia lindheimeri) (1.0\%); all others $(0.3 \%)$.

${ }^{b}$ Val Verde and Terrell counties, Texas. Principal species include acacia (Acacia spp.) (9.6\%), honey mesquite (Prosopis glandulosa) $(4.8 \%)$,

(Acacia spp.) (9.6\%), honey mesquite (

(A cacia spp.) (9.6\%), honey mesquite (Prosopis glandulosa) $(4.8 \%)$, lotewood condalia (Condalia obtusifolia) (3.2\%); all others $(4.8 \%)$.

${ }^{\prime}$ Culberson County, Texas, and Eddy and Otero counties, New Mexico. Principal species include creosotebush (Larrea tridentata) (1.3\%), soapweed (Yucca spp.) (1.2\%), walkingstick cholla (Opuntia imbricata) (1.0\%), fragrant sumac (Rhus aromatica) $(0.6 \%)$; all others $(2.1 \%)$.

availability.

To tentatively examine these possibilities, study areas were compared where the brush cover was different and where food data from local eagle nests were known. Hence, we compared the Trans-Pecos Region with the Val Verde-Terrell County area (Table 9). (No eagle nests were found in the Schleicher-Menard area, precluding a comparison.) We must minimally assume (1) that local livestock populations remained rather constant during the years when eagle nests were active, (2) that our jackrabbit census approximates the lagomorph population of years when the eagle nests were active, and (3) that a valid measure of eagle food habits is shown by the percentage of the total prey animals found as remains in eagle nests (McGahan, 1967, 1968).

From data in Table 9, it appears that eagles preying on lagomorphs may have a difficult time obtaining them where, within the limits of our data $(6-22 \%$ brush cover $)$, there is a greater amount of brush cover. Lambs, on the other hand, constitute a larger percentage of the eagle diet in areas with thicker cover, perhaps because the lagomorphs are merely more difficult to catch in brush habitats.

If the roadside lagomurph census indeed meets assumption 2 , above, then fewer lagomorphs werc taken by eagles in the Val Verde-Terrell area (with $22 \%$ brush cover) even though lagomorphs were about twice as plentiful there as in the Trans-Pecos arca with only $6 \%$ brush cover.

A second and similar comparison was made using the materials collected from the scats of ground carnivores. In this comparison, more so than with the eagle foods, the data were collected at a time concurrent with the lagomorph census. This analysis, also shown in Table 9, further suggests that the lagomorph population was heavily exploited by carnivores where the brush cover was lightest, even though thc lagomorphs were less plentiful in the same area. Conversely, as the amount of brush increased, more evidence of livestock remains was found in the scats.

The terrestrial predators in the Schleicher-Menard area were nonetheless able to secure ample prey from the extremely dense lagomorph population in this region. The magnitude of the lagomorph population in this area presumably resulted in rather large amounts of carrion available as food.

The suggestion presented is that even moderate amounts of brush cover favor the protection of important natural food supplies, such as lagomorphs from both avian and terrestrial carnivores. Their rolc as a buffer against livestock losses seems effectively reduced in brushy habitats.

So far as these data are representative, it appears that eagles feeding in open habitats utilize few livestock. In brushy habitats, however, the eagle-lagomorph food system seems jeopardized by the additional cover and, in turn, these habitats foster additional incidence of livestock in the eagle diet.

\section{Conclusion}

Controversics over the application and magnitude of predator control measures have brought forth new appraisals of land management policies in the last decade (Leopold et al., 1964; Cain et al., 1972). The role of golden eagles in the predator-prey complex nonetheless continues to harbor widely divergent views between some stockmen and conservationists. Some ranchers, for example, still press for resumption of the currently illegal practice of hunting eagles from airplanes.

My view of this controversy proposes that golden eagles are too few throughout much of the sheep-producing areas of Texas (Edwards Plateau) to be of possible importance to the livestock industry. Elsewhere in Texas (Trans-Pecos) and in New Mexico, aircraft surveys indicated that the eagle population is seldom concentrated and has in fact often migrated before serious depredations can occur on lambs.

The few resident eagles, whose nests are now a fraction of their former numbers, primarily feed on lagomorphs and other wildlife foods; the remains of livestock found in eagle nests suggest that the problem is highly local. In fact, the yearly consumption of livestock (i.e., lambs per nest per year) is

Table 9. Comparison of brush cover, golden eagles, and terrestrial carnivores, and roadside lagomorph census. (Data jointly compiled by Robert W. Wiley and Eric G. Bolen.)

\begin{tabular}{|c|c|c|c|c|c|c|c|c|c|c|}
\hline \multirow[b]{2}{*}{ Region } & \multirow[b]{2}{*}{$\begin{array}{l}\text { Brush cover } \\
\text { percent }\end{array}$} & \multicolumn{3}{|c|}{ Eagle foods in nests ${ }^{a}$} & \multicolumn{3}{|c|}{ Scat contentsb } & \multicolumn{3}{|c|}{ Lagomorph census } \\
\hline & & Lagomorph & $\begin{array}{c}\text { Sheep \& } \\
\text { goats }\end{array}$ & Other & Lagomorph & $\begin{array}{c}\text { Shecp \& } \\
\text { goats }\end{array}$ & Other & Miles & Lagomorphs & $\begin{array}{l}\text { Animals/ } \\
s \text { mile }\end{array}$ \\
\hline Trans-Pecos & 6.2 & 75.6 & 8.3 & 16.1 & 38.5 & 0 & 61.5 & 230 & 155 & 0.67 \\
\hline Central Edwards Plateau & 15.3 & - & - & - & 24.9 & 3.2 & 71.9 & 54 & 193 & 3.57 \\
\hline Southwest Edwards Plateau & 22.4 & 45.4 & 13.9 & 40.7 & 8.2 & 10.6 & 81.2 & 80 & 117 & 1.46 \\
\hline
\end{tabular}

a Percentage of total animals represented in nest litter: 10 golden eagle nests were examined in Southwest Edwards Plateau (only Terrell County); for Trans-Pecos, 19 golden eagle nests were examined in Culberson County, Texas, and Eddy and Otero counties, New Mexico.

b Animal remains, expressed as the percentage of the total items, found in scats of terrestrial carnivores collected at each study area; for Trans-Pecos, 25 scats were examined; for Central Edwards Plateau 85; and for Southwestern Edwards Platea 73 scats were examined. 
almost certainly negligible and very likely includes carrion and prey already weakened by other causes.

Extensive appraisals of mortality indicate that about $10 \%$ of the sheep population is lost every year, irrespective of predator controls. Only $25 \%$ of all livestock carcasses found in Texas and New Mexico were the victims of predation. Moreover, research elsewhere clearly suggests that most of the lambs found dead on rangelands were starving at the time they died, irrespective of the actual cause of death.

Finally, measurements of brush cover, eagle foods, mammalian scat contents, and roadside lagomorph censuses suggest that the livestock remains in the diets of eagles and other carnivores increased with brush cover (at least within the limits of 6-22\% cover). Lagomorphs are well represented in the eagle diet where brush cover is minimal and where open country prevails. Thus, in brush-laden habitats, the ubiquitous and well-established eagle-lagomorph food system seems jeopardized, and instead fosters an atypical incidence of livestock in the eagle diet. I take no comfort suggesting that abuses of the land leading to the encroachment of brushy vegetation has perhaps contributed to misjudgment of the golden eagle and its role in livestock management. Regardless of brush cover, however, lagomorphs-and not livestock-comprise the major and natural food of golden eagles.

I firmly believe that too few otherwise healthy lambs fall prey to eagles to justify the killing of either nesting or wintering eagles. There are many causes for the extirpation of species, but for the golden eagle, poisoning, trapping, or shooting should not be among them. To permit such unwarranted exploitation is to ignore both resource management and full appreciation of our wildlife heritage.

\section{Acknowledgments}

Whereas they are in no way responsible for my inferences, opinions, and conclusions, I wish to acknowledge the helpful reviews provided by Billie E. Dahl, Jerran T. Flinders, J. Michael Lockhart, and John H. Rappole. Frank A. Hudson provided much of the background information concerning lamb mortality. Robert W. Wiley, now with the University of Arkansas at Monticello, graciously permitted me to use unpublished field data we jointly developed although, he, too, must not bear the burden of my opinions. I am especially indebted to Donald F. Burzlaff and to the Society for Range Management for providing me the opportunity to express my views without the constraints normally appropriate in reporting research-my position is clearly shaded yet not, I trust, without some factual merit for its foundation.

\section{Literature Cited}

Alford, J. R., and E. G. Bolen. 1972. A note on golden cagle talon wounds. Wilson Bull. 84:487-489.

Bent, A. C. 1937. Life histories of North American birds of prey. Part 1. Bull. U.S. National Mus., Washington, D.C. 409 p.

Boeker, E. L., and E. G. Bolen. 1972. Winter golden eagle populations in the Southwest. J. Wildl. Manage. 36:477-484.

Cain, S. A., J. A. Kadlec, D. L. Allen, R. A. Cooley, M. G. Hornocker, A. S. Leopold, and F. H. Wagner. 1972. Predator control-1971: report to The Council on Envirommental Quality and The Department of the Interior. Instit. for Environ. Quality, Univ. of Michigan, Ann Arbor. $207 \mathrm{p}$.

Errington, P. L. 1967. Of predation and life. Iowa St. Univ. Press, Ames. 277 p.

Ford, H. S., and J. R. Alcorn. 1964. Observations of golden eagle attacks on coyotes. Condor 66:76-77.

Leopold, A. S., S. A. Cain, C. Cottam, I. N. Gabrielson, and T. L. Kimball. 1964. Predator and rodent control in the United States. Trans. North Amer. Wildl. Conf. 29:27-49.

Livestock and Crop Reporting Service. 1968. Texas sheep and goat industry. U.S. Dep. Agr. and Texas Dep. of Agr., Austin. 58 p.

McGahan, J. 1967. Quantified estimates of predation by a golden eagle population. J. Wildl. Manage. 31:496-501.

McGahan, J. 1968. Ecology of the golden eagle. Auk 85:1-12.

Mollhagen, T. R., R. W. Wiley, and R. L. Packard. 1972. Prey remains in golden eagle nests: Texas and New Mexico. J. Wildl. Manage. $36: 784-792$.

Rowley, I. 1970. Lamb predation in Australia: incidence, predisposing conditions, and the identification of wounds. CSIRO Res. $15: 79-123$.

Safford, J. W., and A. S. Hoversland. 1960. A study of lamb mortality in a western range flock. I-Autopsy findings in 1051 lambs. J. Anim. Sci. 19:265-273.

Vetter, R. L., H. W. Norton, and U.S. Garrigus. 1960. A study of preweaning death losses in lambs. J. Anim. Sci. 19:616-619.

Wagner, F. H. 1972. Coyotes and sheep. Utah State University Faculty Honor Lecture, Logan. 59 p.

White, M. 1973. Description of remains of deer fawns killed by coyotes. J. Mammalogy 54:291-293.

Wiley, R. W., and E. G. Bolen. 1971. Eagle-livestock relationships: livestock carcass census and wound characteristics. Southwestern Nat. 16:151-169.

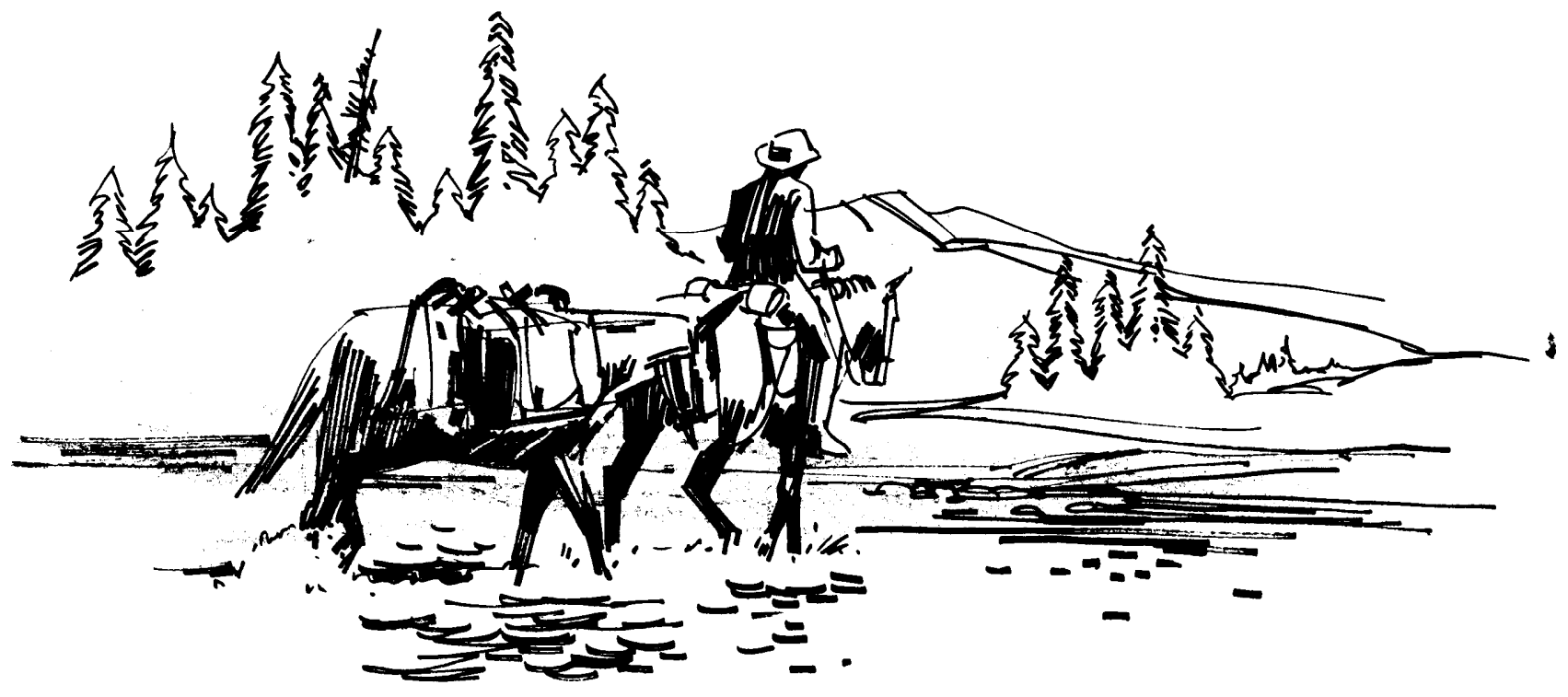

